\title{
Die verhouding tussen ouer en jonger geslagte in die Nuwe Testament: 'n Filologiese studie
}

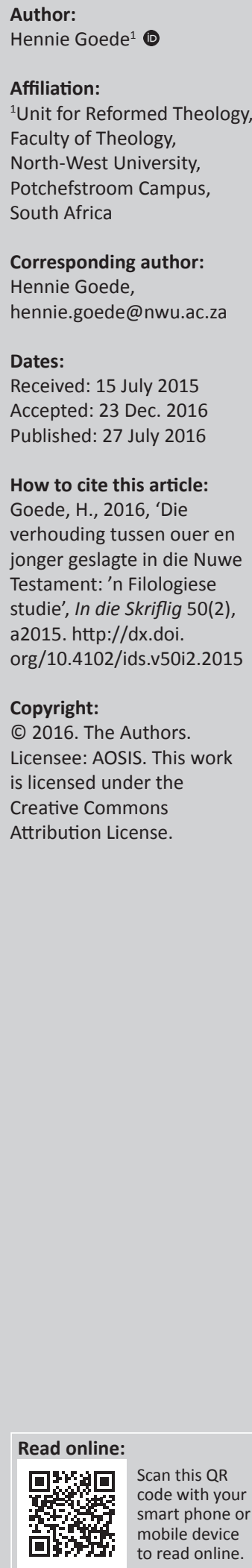

\begin{abstract}
The relationship between older and younger generations in the New Testament: A philological study. Churches experience tension between the ministry needs of younger and older generations in the congregation. A focus on either one or the other brings polarisation in congregations between younger and older members. The profile of the Early Church as sketched in the New Testament, however, draws a picture in which both younger and older generations are ministered. This study investigates texts from the New Testament philologically which sketch this picture and attempts to draw conclusions therefrom which can provide possible solutions to the tension between the ministry needs of younger and older generations in congregations. From this philological study it appears among others that the congregation must consist in its nature of younger and older members and that ministry practices must do justice to both groups. They are indeed all part of the household of God and thus spiritual brothers and sisters of one another. A healthy relationship between younger and older generations in the church is built on reciprocal respect, love, humility, and willingness to serve. When congregations implement these aspects and others in their ministry practices, they move closer to the New Testament image of a church in which both young and old believers have a place to serve and to be served.
\end{abstract}

\section{Inleiding}

Kerke ervaar ' $n$ spanning in die bedieningsbehoeftes van jonger en ouer geslagte lidmate in gemeentes. In gemeentes met ' $n$ toenemend ouer lidmaattal moet die behoeftes van jonger lidmate ook in aanmerking geneem word, anders raak laasgenoemde groep vir sulke gemeentes verlore. Gemeentes wat doelgerig op die behoeftes van jonger lidmate fokus, se profiel sluit tipies min ouer lidmate in. Die profiel van die Vroeë Kerk soos dit in die Nuwe Testament opgeteken is, skets egter 'n prentjie waarin sowel 'n jonger as 'n ouer geslag bedien word. Hierdie studie ondersoek tekste in die Nuwe Testament wat hierdie beeld skets en poog om gevolgtrekkings daaruit te maak wat moontlike oplossings vir die spanning tussen die bedieningsbehoeftes van jonger en ouer geslagte in gemeentes kan bied.

\section{Probleemstelling}

Die kerk het regdeur sy geskiedenis nog altyd 'n noue band met gesinne en families gehad (Garland 1999). Vandag staan die kerk voor 'n nuwe uitdaging wat gesinne en families betref, naamlik hoe om hierdie unieke band weer tot voordeel van gesinne maar ook tot die voordeel van gemeentes te versterk (Van Staden \& Dreyer 2013:1). Binne die kerk het 'n polarisasie tussen kinders en hulle ouers ontstaan en die volgende redes kan hiervoor aangevoer word (Renfro, Shields \& Strother 2009:26 e.v.):

- Die opkoms van adolessensie as portuurgroep en die samelewing se hantering van hierdie ekonomies aktiewe groep as 'a tribe apart' wat deur volwassenes eenkant toe geskuif is en nou die fokus van bemarkers geword het.

- Die kerk se reaksie op hierdie sosiale verskynsel, naamlik ouderdom-gefokusde bediening wat deur professionele jeugbedienaars aangebied en wat die bediening vir adolessente aantreklik moes maak.

- Die gevolg van ouderdom-gefokusde bediening aan jongmense, naamlik dat die verantwoordelikheid vir hulle geestelike groei deur ouers op jeugbedienaars afgeskuif is, omdat die gaping tussen ouers se belewing en uitleef van hulle geloof en dié van hulle kinders (van alle ouderdomme) al hoe groter geword het. Ouers se betrokkenheid in kategese en belydenisaflegging het ook afgeneem.

- Die gevolg is die verlies aan integrasie tussen jonger en ouer geslagte in gemeentes (dus wyer as net die gesin). 
Die kerk worstel ook met die hersamestelling van gesinne in die samelewing vandag. Die tradisionele norm van 'n kerngesin met ' $n$ pa, ma en kinders is nie meer die norm nie. Anthony (2011) beskryf hierdie proses van hersamestelling as 'the morphing of the family'. Gesinne neem vandag verskillende vorms aan: enkelouergesinne as gevolg van dood of egskeiding, hersaamgestelde gesinne as gevolg van hertrou na'n egskeiding of die dood, saamwoonverhoudings, gay en lesbiese verhoudings. 'n Mens sou ook nog kon byvoeg: aanneemgesinne, gesinne waar kinders verwek is deur in-vitro-behandeling en drie- of viergenerasiefamilies (Van Staden 2014:1). Dan kom die enkellopendes en die weduwees en wewenaars ook nog by. Binne die konteks van die bediening aan jonger en ouer geslagte binne 'n gemeente moet die werklikheid van hierdie morfering van gesinne deeglik erken en verreken word.

\section{'n Filologiese studie}

In hierdie studie is die relevante tekste uit die Nuwe Testament filologies ondersoek. Die linguis bestudeer taal ter wille van taal sonder om noodwendig die historiese en kulturele aspekte daarvan in ag te neem (Goede 2006:13). Daarteenoor bestudeer die filoloog taal met ' $n$ ander doel, en benut die resultate van sy studie van taal om 'n ander doel te bereik, byvoorbeeld die interpretasie van 'n ander teks. ${ }^{1}$ 'n Filologiese studie van antieke tekste behels die bestudering van sodanige teks deur middel van 'n taalanalise binne die teks se sosio-historiese konteks. So 'n filologiese studie sluit egter nie die gebruik van linguistiese metodologieë, beginsels en metodes uit nie, afhangend van die aard van die antieke teks wat ondersoek word (2006:14).

'n Filologiese studie soos hierbo beskryf, kan met 'n grammaties-historiese benadering belyn word tot 'n eksegese van die Nuwe Testament waarin die sosio-historiese konteks van die teks behoorlik verreken word (De Klerk et al. 2011:139-158). In die bepaling van die sosio-historiese kontekste van die Nuwe-Testamentiese tekste wat in hierdie artikel ondersoek word, is die sosio-historiese benadering soos deur Harrill (1998:4-6) en Janse van Rensburg (2000) beskryf is, gevolg. Volgens hierdie benadering stel die filoloog sy vooronderstellings uitdruklik en poog hy om dit maksimaal te beheer met die doel om die mees waarskynlike werklike sosio-historiese konteks van die teks so realisties as moontlik te konstrueer (Harrill 1998:5). Die doel van hierdie artikel is om die sosio-historiese konteks van die verhouding tussen jonger en ouer geslagte in die Vroeë Kerk te ondersoek as deel van 'n breër filologiese analise van die relevante tekste in die Nuwe Testament.

\section{Die Nuwe Testament oor verskillende geslagte in die kerk}

Die volgende tekste werp vanuit die Nuwe Testament lig op die verhouding tussen jonger en ouer generasies in die Vroeë Kerk: Efesiërs 6:1-4 (Figuur 1), Kolossense 3:20-21 (Figuur 2),

1.Vir 'n volledige beredenering van die verskille tussen filologie en linguistiek, sien Goede (2006).
1 Timoteus 4:12 (Figuur 3), 1 Timoteus 5:1-2 (Figuur 4), Titus 2:1-8 (Figuur 5), 1 Petrus 5:5 (Figuur 6) en 1 Johannes 2:12-17 (Figuur). Sien Figure 1 tot 7 hieronder. $^{2}$

\section{Uitgangspunte vir die effektiewe bediening van jonger en ouer geslagte in die kerk}

Die filologiese ontleding van bogenoemde NuweTestamentiese tekste het sekere uitgangspunte vir die effektiewe bediening van jonger en ouer geslagte in die kerk aan die lig gebring. Hierdie uitgangspunte sou soos volg in die praktiese bediening van jonger en ouer lidmate deur kerke en gemeentes verreken kon word:

- Die Ou-Testamentiese oproep tot kinders om hulle ouers (en by implikasie alle ouer mense) te eer, word bevestig. Kerklike bedieningspraktyke mag nie die indruk by jonger lidmate skep dat disrespek teenoor ouer mense die norm is nie, of dat ouer lidmate niks vir hulle geloofsgroei kan en moet beteken nie.

- Ouers bly primêr vir hulle kinders se geloofsgroei verantwoordelik. Hoewel die kerk 'n belangrike rol daarin speel, mag ouers nie hulle verantwoordelikheid op die kerk of ander gelowiges afskuif, of aangemoedig word om dit te doen nie.

- Die gesinstruktuur bly 'n bousteen van die kerk selfs te midde van die veranderings wat in hierdie struktuur waargeneem word. Bedieningspraktyke moet vir die bediening van alternatiewe gesinne voorsiening maak.

- Jonger én ouer geslagte moet Christus se heerskap oor hulle erken en dit moet ook in die bedieningspraktyke tot uiting kom. Geen groep mag oor die ander heers en so die uitsluitlike bedieningspraktyk bepaal nie.

- Ouderdom speel geen rol in die diens van gelowiges aan God en in die kerk van sy Seun nie. Die lewenswyse van elke gelowige is eerder bepalend. Bedieningspraktyke moet daarop gerig wees om vir elke gelowige ongeag ouderdom ruimte te gee, om te dien.

- Die gemeente moet 'n verwelkomende ruimte vir gelowiges van alle ouderdomme bied en so die gemeenskap waarin die gemeente kerk is, weerspieël. Dit beteken egter nie dat alle bedieningspraktyke dieselfde hoef te wees nie. Lidmate en kerkleiers behoort sensitief vir lidmate se ouderdomspesifieke behoeftes te wees, sonder om die geestelike familieband wat deur Christus en sy Gees tussen hulle gesmee is, te laat verslap.

- Die verhouding tussen jonger en ouer geslagte word uitdruklik as wederkerig getipeer. Albei groepe is nederigheid aan mekaar verskuldig, en by implikasie dus ook diensbaarheid. Prakties beteken dit dat die twee groepe nie van mekaar geskei of weggehou mag word nie, want anders word hulle die geleentheid ontneem om nederigheid en diensbaarheid te betoon.

2.Die keuse van tekste is deur die fokus van die studie bepaal, naamlik die verhouding tussen je van tekste is deur die fokus van die studie bepaal, naamlik die verhouding tussen jonger en ouer ges tekste nie direk op gemeentebediening betrekking het nie, werp dit wel lig op hierdie verhoudings as deel van die sosio-historiese konteks van die Nuwe Testament. 


\section{Perikoop:}

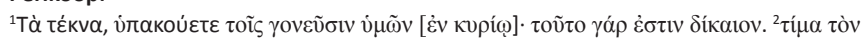

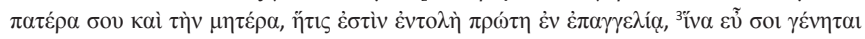

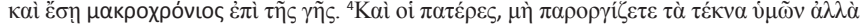

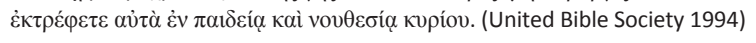

\section{Eie vertaling:}

${ }^{1}$ Kinders, wees gehoorsaam aan julle ouers [in die Here], want dit is hoe dit hoort. ${ }^{2}$ Eer jou vader en jou moeder - dit is die eerste gebod met ' $n$ belofte $-{ }^{3}$ sodat dit met jou goed mag gaan en jy lank op die aarde sal lewe. ${ }^{4} E n$ vaders, moenie julle kinders uittart nie maar maak hulle groot met [die] dissipline en teregwysing van die Here.

Plek van die perikoop in die boek:

(Oorgeneem en vertaal uit Furnish 1996b:536)

1. Aanhef van die brief $(1: 1-2)$

1.1 Geadresseerdes (1:1-2)

1.2 Seëngroet (1:3-14)

1.3 Danksegging (1:15-23)

2. Liggaam van die brief $(2: 1-6: 20)$

2.1 Bevestigings van die geheimenis van Christus (2:1-3:21)

2.1.1 Opstanding en versoening (2:1-22)

2.1.2 Die apostel se rentmeesterskap van God se genade (3:1-13)

2.1.3 Gebed en lofprysing (3:14-21)

2.2 Oproepe om 'n Christelike lewe te lei (4:1-6:20)

2.2.1 Basiese oproepe (4:1-24)

2.2.1.1 Handhaaf die eenheid van die Gees (4:1-16)

2.2.1.2 Trek die ou natuur uit (4:17-22)

2.2.1.3 Trek die nuwe natuur aan (4:23-24)

2.2.2 Spesifieke oproepe (4:25-6:9)

2.2.2.1 Verskeidenheid onderwerpe (4:25-5:20)

2.2.2.2 Lewe in die huishouding (5:21-6:9)

2.2.2.2.1 Man en vrou (5:21-33)

2.2.2.2.2 Ouers en kinders $(6: 1-4)$

2.2.2.2.3 Eienaars en slawe (6:5-9)

2.2.3 Afsluiting van oproepe (6:10-20)

2.2.3.1 Trek die volle wapenrusting van God aan (6:10-17)

2.2.3.2 Bid in die Gees (6:18-20)

3. Afsluiting van die brief $(6: 21-24)$

3.1 Aanbeveling vir Tigikus (6:21-22)

3.2 Seëngroet $(6: 23-24)$

Efesiërs 6:1-4 vorm deel van die oproepe oor die lewe van die gelowige in die huishouding (2.2.2.2: 5:21-6:9). Hierdie spesifieke oproepe is gewortel in die basiese oproepe in 2.2.1: 4:1-24, wat weer op hulle beurt geanker is in bevestigings oor Christus en sy versoeningswerk (2.1: 2:1-3:21). Die brief as geheel sentreer rondom die hoofskap van Christus (Ef 1:10; vgl. Furnish 1996b:538) wat eenheid in sy liggaam, die kerk, noodsaak (Ef 4:3). Hierdie eenheid moet ook in die huishouding tot uiting kom, en dan spesifiek in die verhouding tussen ouers en kinders. Die rigtinggewende beginsel vir die gelowige lewe in die huishouding word in Efesiërs 5:21 weergegee: vं X

Genre van die perikoop en van die boek:

Die genre van hierdie perikoop, sowel as die groter eenheid waarin dit voorkom (5:21-6:9), is dié van huistafels. Aune (1987:194-197) asook Bailey en Vander Broek (1992:62-69) beskou huistafels as ' $n$ vorm van paraenesis of advies wat algemene of godsdienstige lering bevat. In die Nuwe Testament word die huistafels gebruik om die kerk as huisgesin van God (Ef 2:19) na analogie van die huishouding te vorm (Aune 1987).

Ontleding van die gedagtestruktuur van die perikoop:

Oproep tot kinders

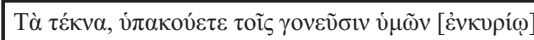

$\longrightarrow$ Rede vir die oproep

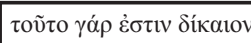

Nadere verklaring van die basiese oproep

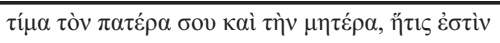

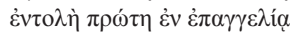

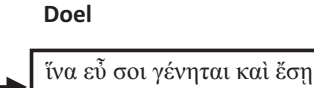

$\mu \alpha \kappa \rho о \chi \rho o ́ v \operatorname{s~}$

Negatiewe oproep tot ouers

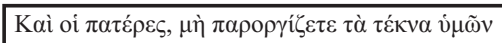

$\longrightarrow$ Positiewe oproep tot ouers

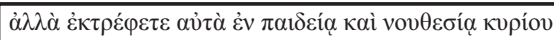

Sosio-historiese konteks van die perikoop:

Die Grieks-Romeinse huishouding in die tyd van die Nuwe Testament het rondom die man as hoof (die paterfamilias) gesentreer (Jeffers 1999:238). Hy het absolute mag oor sy vrou, kinders, slawe, vrygestelde slawe en eiendom uitgeoefen. Dissipline oor die kinders is deur albei ouers uitgeoefen. Daar is van kinders verwag om aan hulle ouers onderdanig te wees en hulle ouers te respekteer (1000). Gesinne het 'n baie prominente rol in die Vroeë Kerk gespeel (bv. Hand 16:32) aangesien die paterfamilias ook alleenseggenskap oor godsdienstige sake gehad het. Trouens huishoudings was sentraal tot die totstandkoming van die Vroeë Kerk en die gebruik om in huise te vergader (Osiek \& Balch 1997:32-35).

FIGUUR 1: Efesiërs 6:1-4. 
Studie van belangrike konsepte in die perikoop:

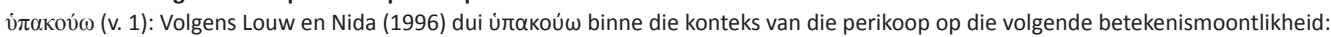

- om te gehoorsaam omdat aandag gegee het aan (36.15 domein 36C Gehoorsaam, ongehoorsaam).

Die gehoorsaamheid wat van kinders teenoor hulle ouers verwag word, hou in dat hulle met aandag na hulle ouers luister (vgl. عiøakoúw binne dieselfde domein) en dan daarvolgens optree (Bauer 2000h). Hierdie gehoorsaamheid is in die gelowige se gehoorsaamheid aan Christus gewortel (Mundle 1986).

$\pi \alpha \rho \rho \rho i \zeta \omega$ (v. 3): Volgens Louw en Nida (1996) en (Bauer 2000e) verwys $\pi \alpha \rho \circ \gamma \gamma \zeta \zeta \omega$ na die volgende betekenismoontlikheid:

- om iemand kwaad te maak of woede by iemand uit te lok ( 88.177 domein $88 \mathrm{X}$ Woede, verontwaardig wees).

In hierdie konteks is dit duidelik dat die verbod teen vaders ten doel het om optrede wat hulle kinders kwaad maak of woede by hulle ontlok, uit te skakel.

кúpı (v. 4): Volgens Louw en Nida (1996) en (Bauer 2000b) dui kúpıoৎ kontekstueel op die volgende betekenismoontlikhede:

- 'n eienaar van eiendom (57.12 domein 57A Hê, besit, eiendom, eienaar);

- 'n regeerder (37.51 domein 37D Heers, regeer);

- die titel vir God en Christus naamlik Here (12.9 domein 12A Bonatuurlike wesens).

As paterfamilias was die vader van kinders ook in 'n sekere sin hulle heer.

\section{Openbaringshistoriese konteks van die perikoop:}

Die perikoop trek'n openbaringshistoriese lyn vanuit die vyfde gebod in die Tien Gebooie (Eks 20:12; Deut 5:16). Kinders in die Vroeë Kerk is steeds aan die vyfde gebod gebonde, naamlik dat hulle hulle ouers moet eer. Ouers word ook steeds opgeroep om hulle kinders in die Here, met ander woorde in die wil van die Here, groot te maak (Deut 6:6-7). Ouers bly dus primêr vir hulle kinders se geloofsgroei verantwoordelik. Die verhouding tussen ouers en kinders word egter ook in 'n nuwe lig gestel, naamlik dié van gelowige ouers en kinders se verhouding met Jesus Christus. Hy is vir sowel jonger as ouer gelowiges hulle Here, en daarom werk die verhouding weerskante toe soos Efesiërs $5: 21$ dit duidelik maak: 'Wees aan mekaar onderdanig uit eerbied vir Christus.' Die Nuwe Testament weerspieël 'n baie groter mate van wederkerigheid in die verhoudings in die huishouding as in die Grieks-Romeinse wêreld (Jeffers 1999:249) soos ook in die kerk (vgl. Kol 3:28).

\section{Openbaring oor God in die perikoop:}

God openbaar Homself in Christus as God en Heer van jonger en ouer gelowiges, en Hy diskrimineer nie teen die een óf die ander groep nie. God se besondere bemoeienis met kinders en jongmense spreek uit die geheel van die Skrif - veral uit die aardse bediening van Jesus (vgl. Mark 5:35-43; 9:14-29; 10:13-16).

\section{Verlossingsfeite in die perikoop:}

Die titel, kúplos, impliseer Christus se heerskap oor hulle wat in Hom glo. Sy heerskap is bevestig deur sy dade van verlossing aan die kruis en deur sy opstanding, en veral die feit dat Hy met sy kosbare bloed alle gelowiges - oud en jonk - losgekoop het om sy eiendom te wees (vgl. 1 Pet 1:18-19). In hierdie titel word die verlossingsfeite erken en bely soos die Evangelies dit in die lewens van gelowiges weergee.

\section{Oproepe tot jonger en ouer geslagte in die perikoop:}

Kinders word steeds opgeroep om hulle ouers te eer, en ouers word steeds opgeroep om hulle kinders volgens die wil van God groot te maak. Sowel kinders as ouers, dus die jonger en die ouer geslag, word tot wederkerige onderdanigheid opgeroep. Anders gestel: jonger en ouer geslagte word opgeroep om liefde teenoor mekaar te bewys (Ef 4:2; 5:2).

\section{Die kommunikasiedoel van die perikoop:}

Deur hierdie perikoop motiveer die Heilige Gees kinders en ouers, jonger en ouer geslagte, om só teenoor mekaar op te tree dat die effek van Christus se verlossingswerk, naamlik sy heerskap oor hulle almal, duidelik word.

Uitgangspunt(e) afgelei uit die perikoop vir die bediening van jonger en ouer geslagte:

- Die Ou-Testamentiese oproep tot kinders om hulle ouers te eer, word bevestig.

- Ouers bly primêr vir hulle kinders se geloofsgroei verantwoordelik.

- Die verhouding tussen kinders en ouers, en dus jonger en ouer geslagte, word ook in die konteks van Christus se verlossingswerk en sy heerskap oor alle gelowiges geplaas, ongeag hulle ouderdom. Vaders moet onthou dat Christus húlle Here is, en ook dié van hulle kinders.

- Hierdie konteks noodsaak jong en ouer gelowiges om aan mekaar onderdanig te wees en in liefde teenoor mekaar op te tree, eerder as met disrespek en ongehoorsaam aan die kant van die jongeres, en 'n optrede wat tot rebellie lei aan die kant van die oueres.

FIGUUR 1 (vervolg...): Efesiërs 6:1-4.

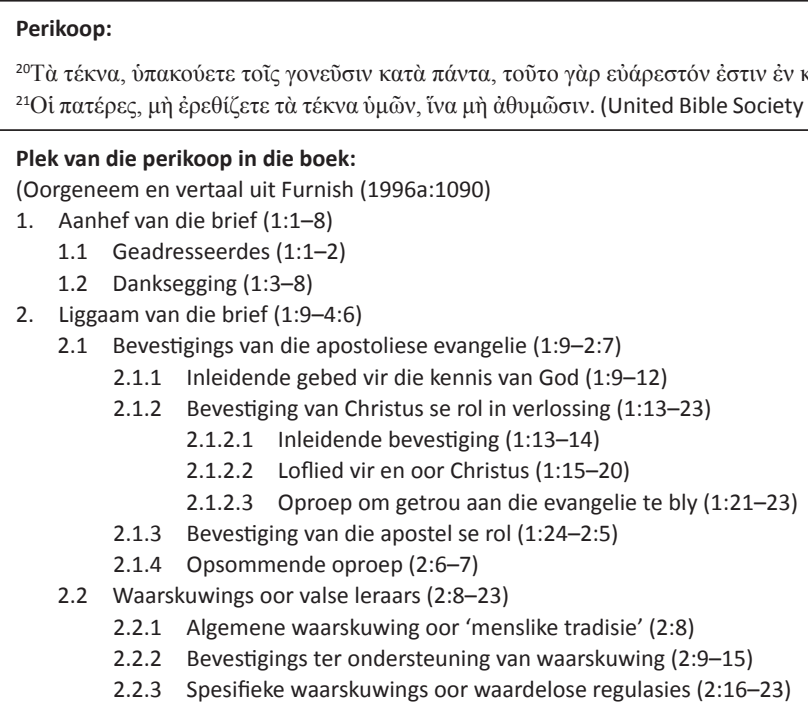

FIGUUR 2: Kolossense 3:20-21.

\section{Eie vertaling:}

${ }^{20}$ Kinders, wees in alles aan julle ouers gehoorsaam, want dit is aanvaarbaar onder die beheer van die Here. ${ }^{21}$ Vaders, moenie julle kinders treiter sodat hulle moed verloor nie. 
2.3 Oproepe om 'n Christelike lewe te lei (3:1-4:6)

2.3.1 Basiese oproepe (3:1-17)

2.3.1.1 Soek die dinge wat daarbo is (3:1-4)

2.3.1.2 Trek die ou natuur uit (3:5-11)

2.3.1.3 Trek die nuwe natuur aan (3:12-17)

2.3.2 Raad oor die daaglikse lewe (3:18-4:6)

2.3.2.1 Die huishouding (3:18-4:1)

2.3.2.1.1 Vroue en mans (3:18-19)

2.3.2.1.2 Kinders en ouers $(3: 20-21)$

2.3.2.1.3 Slawe en eienaars $(3: 22-4: 1)$

2.3.2.2 Gebed (4:2-4)

2.3.2.3 Buitestanders $(4: 5-6)$

3. Afsluiting van die brief (4:7-18)

3.1 Nuus en groete van die skrywer se medewerkers (4:7-14)

3.2 Aangaande die kerk in Laodisea (4:15-16)

3.3 Aangaande Argippus (4:17)

3.4 Outografiese slot en seëngroet $(4: 18)$

Hierdie perikoop vorm deel van 'n groter eenheid wat oor die verhoudings in die huishouding handel (2.3.2.1: 3:18-4:1)). Die oproepe in 2.3.2.1 (en dus ook dié in 3:20-21) is in die basiese oproepe in 2.3.1 gewortel, wat op hulle beurt weer in die bevestiging van Christus se rol in die verlossing in 2.1.2 gewortel is.

Soos in die brief aan die Efesiërs, word die hoofskap van Christus wat op sy verlossingswerk (1:14) gebaseer is, bevestig (veral in 1:15-20). Dit impliseer gemeenskap met Hom in sy dood en opstanding (2:6-3:4). Hierdie gemeenskap met Christus lei tot ' $n$ verandering in die leefstyl van die gelowige (3:5-17). Hierdie verandering raak ook die verhouding tussen gelowige ouers en kinders.

Genre van die perikoop en van die boek:

Die genre van hierdie perikoop, sowel as die groter eenheid waarin dit voorkom (3:18-4:1), is dié van huistafels (sien bespreking by Efesiërs 6:1-4 hierbo).

\section{Ontleding van die gedagtestruktuur van die perikoop:}

Oproep tot kinders

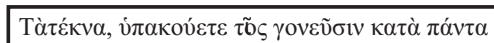

$\rightarrow$ Rede vir die oproep

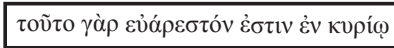

Negatiewe oproep tot ouers

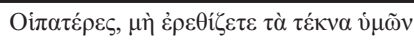

$\rightarrow$ Doel van die negatiewe oproep

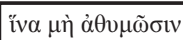

Sosio-historiese konteks van die perikoop:

Sien Efesiërs 6:1-4 hierbo.

Studie van belangrike konsepte in die perikoop:

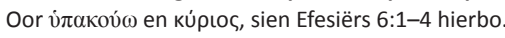

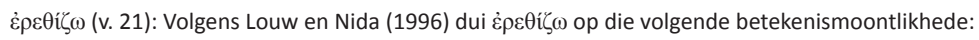

- verbitterd maak (88.168 domein 88W Verbitterd, 'n wrok teen iemand hou);

- veroorsaak (90.55 domein 90L Agent in 'n kousatiewe rol met werkwoord as merker) (Bauer 2000a).

In die konteks van die perikoop pas die eerste moontlikheid die beste (hoewel die tweede beslis geïmpliseer word). Vaders se optrede moet dus nie veroorsaak dat hulle kinders verbitterd teenoor hulle word of ' $n$ wrok teen hulle koester nie.

\section{Openbaringshistoriese konteks van die perikoop:}

Die openbaringshistoriese lyn uit die Ou-Testament, naamlik dat kinders hulle ouers moet eer - soos aangedui in die analise van Efesiërs 6:1-4 - is ook hier van toepassing, hoewel dit geïmpliseer eerder as uitdruklik gestel word. Weereens word die verhouding tussen kinders en ouers nou ook in die lig van Christus se heerskap oor alle gelowiges gestel, en daarom die opdrag aan ouers om hulle kinders nie verbitterd te maak nie, maar in liefde teenoor hulle op te tree (vgl. Kol 1:4; 2:2).

Openbaring oor God in die perikoop:

God openbaar Homself in Christus as God en Heer van jonger en ouer gelowiges, en Hy diskrimineer nie teen die een óf die ander groep nie. God se besondere bemoeienis met kinders en jongmense spreek uit die geheel van die Skrif, en veral uit die aardse bediening van Jesus (vgl. Mark 5:35-43; 9:14-29; 10:13-16).

Verlossingsfeite in die perikoop:

Die titel, kúpısc, impliseer Christus se heerskap oor hulle wat in Hom glo. Sy heerskap is deur sy dade van verlossing aan die kruis bevestig en deur sy opstanding, en veral die feit dat Hy met sy kosbare bloed alle gelowiges - oud en jonk - losgekoop het om sy eiendom te wees (vgl 1 Pet 1:18-19). In hierdie titel word die verlossingsfeite erken en bely soos deur die Evangelies in die lewens van gelowiges weergegee word.

\section{Oproepe tot jonger en ouer geslagte in die perikoop:}

Kinders word steeds opgeroep om hulle ouers te eer, en ouers word steeds opgeroep om hulle kinders volgens die wil van God groot te maak. Sowel kinders en ouers, dus die jonger en die ouer geslag, word opgeroep om liefde teenoor mekaar te bewys (Kol 1:4; 2:2; vgl. Ef 4:2; 5:2).

\section{Die kommunikasiedoel van die perikoop}

Deur hierdie perikoop motiveer die Heilige Gees kinders en ouers, jonger en ouer geslagte, om só teenoor mekaar op te tree dat die effek van Christus se verlossingswerk, naamlik sy heerskap oor hulle almal, duidelik word.

FIGUUR 2 (vervolg...): Kolossense 3:20-21. 
Uitgangspunt(e) afgelei uit die perikoop vir die bediening van jonger en ouer geslagte:

Die Ou-Testamentiese oproep tot kinders om hulle ouers te eer, word bevestig.

Tog word die verhouding tussen kinders en ouers, dus jonger en ouer geslagte, ook in die konteks van Christus se verlossingswerk geplaas en sy heerskap oor alle gelowiges, ongeag ouderdom.

Hierdie konteks noodsaak jong en ouer gelowiges om aan mekaar onderdanig te wees en in liefde teenoor mekaar op te tree, eerder as met disrespek en ongehoorsaam aan die kant van die jongeres, en 'n optrede wat tot verbittering kan lei aan die kant van die oueres.

FIGUUR 2 (vervolg...): Kolossense 3:20-21.

\section{Perikoop:}

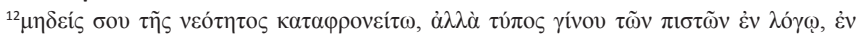

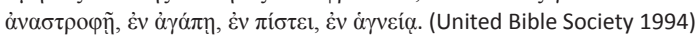

\section{Eie vertaling:}

${ }^{12}$ Laat niemand jou jonk-wees minag nie, maar wees ' $n$ voorbeeld vir die gelowiges in woord, in gedrag, in liefde, in geloof [en] in reinheid.

\section{Plek van die perikoop in die boek:}

(Vgl. Cooetzee 1975:104-105)

1. Aanhef tot die brief (1:1-2)

1.1 Sender (1:1)

1.2 Geadresseerde (1:2a)

1.3 Seëngroet (1:2b)

2. Oordrag van die bediening van die ware evangelie aan Timoteus (1:3-20)

2.1 Waarskuwing teen valse lerings (1:3-11)

2.2 Dankbare terugkyk op Paulus se bediening van die Woord (1:12-17)

2.3 Oordrag van die boodskap aan Timoteus (1:18-20)

3. Pastorale opdragte aan Timoteus (2:1-6:10)

3.1 Bid vir alle mense (2:1-8)

3.2 Die plek van vroue in die gemeente (2:9-15)

3.3 Kwalifikasies vir opsigters (3:1-16)

3.4 Toegewyde prediking en afwys van dwaalleer $(4: 1-16)$

3.5 Opdragte oor die bediening van die gemeente $(5: 1-6: 2 a)$

3.5.1 Behandel die gemeente soos familie $(5: 1-2)$

3.5.2 Bediening aan weduwees (5:3-16)

3.5.3 Bediening saam met die ouderlinge (5:17-20)

3.5.4 Onbevooroordeeld en geduldig wees $(5: 21-25)$

3.5.5 Bediening aan slawe (6:1-2a)

3.6 Valse leraars en ware tevredenheid $(6: 2 b-10)$

4. Persoonlike oproepe tot Timoteus as 'man van God' (6:11-20a)

5. Afsluiting van die brief $(6: 20 \mathrm{~b})$

5.1 Seëngroet $(6: 20 b)$

Hierdie perikoop vorm deel van die groter geheel wat opdragte aan Timoteus bevat oor hoe om 'n goeie dienaar van Christus te wees (3.4: 4:1-16). Sy jonkheid word hier eksplisiet aan die orde gestel, klaarblyklik omdat daar lidmate in die gemeente was wat sou verkies het as hy ouer en meer ervare in die bediening was.

\section{Genre van die perikoop en van die boek:}

Hierdie perikoop kan beskou word as paraenesis of die gee van advies (Aune 1987; Bailey \& Vander Broek 1992). Die advies kan bemoediging, waarskuwing, vermaning teregwysing of lofprysing insluit en is ' $n$ indirekte wyse om 'n gedragsprobleem te hanteer (Aune 1987:194). In hierdie geval word die advies aan Timoteus gee. As jong leraar het hy 'n sekere lewenswyse gevolg en word hy deur die skrywer daarvoor geloof en aangemoedig om daarin te volhard. Die regstelling van gedrag is dus nie teen Timoteus gerig nie, maar wel teen die lidmate wat sy jonkheid teen hom gehou het.

\section{Ontleding van die gedagtestruktuur van die perikoop:}

Bemoediging dat ouderdom nie bepalend is nie

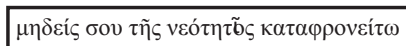

$\rightarrow$ Teenstelling dat lewenswyse eerder bepalend is

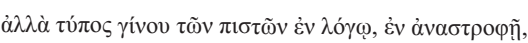

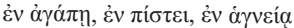

Sosio-historiese konteks van die perikoop:

Die situasie waarin Timoteus hom bevind, gaan teen die grein van die Grieks-Romeinse samelewing in waar ouer persone gesag oor jonger mense uitoefen, en nie andersom nie (Marshall 2004:560).

Studie van belangrike konsepte in die perikoop:

vعótnc: Volgens Louw en Nida (1996) en Bauer (2000d) verwys veótnৎ na die enkele betekenismoontlikheid:

- jeug (67.154 domein 67H Onbepaalde eenhede van tyd: Ouderdom, leeftyd, interval, periode).

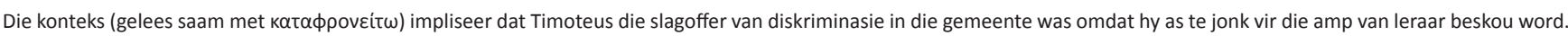

Openbaringshistoriese konteks van die perikoop:

Openbaringshistories is daar presedente vir jong dienaars van die Here: Josef (Gen 41:12), Samuel (1 Sam 3:1), en Dawid (1 Sam 16:11, 18). Dat Timoteus dus op 'n jong ouderdom as man van God (1 Tim 6:11) sou dien, is nie vreemd nie. Trouens nêrens in die Skrif word ouderdom as die bepalende kwalifikasie vir diens aan God en sy gemeente voorgehou nie.

Openbaring oor God in die perikoop:

God roep mense tot sy diens waar, hoe en op watter ouderdom Hy wil.

FIGUUR 3: 1 Timoteus 4:12 


\section{Verlossingsfeite in die perikoop:}

Die lewenswyse van die voorgangers in God se gemeente word nie deur ouderdom bepaal nie, maar eerder deur die vernuwende effek van Christus se verlossingswerk in diegene wat in Hom glo, asook die vernuwende werk van sy Gees.

\section{Oproepe tot jonger en ouer geslagte in die perikoop:}

Jonger gelowiges word opgeroep om hulle plek in die diens van God vol te staan, en ouer gelowiges moet besef dat jongeres ook die leiding kan en mag neem. Ouer gelowiges mag nie teen jong gelowiges op grond van hulle jeug diskrimineer nie.

\section{Die kommunikasiedoel van die perikoop:}

Deur hierdie perikoop motiveer die Heilige Gees jong gelowiges om hulle plek in God se diens vol te staan, en ouer gelowiges om jongeres nie aan hulle ouderdom te oordeel nie, maar eerder na aanleiding van hulle leefwyse.

\section{Uitgangspunt(e) afgelei uit die perikoop vir die bediening van jonger en ouer geslagte:}

Ouderdom speel geen rol in die diens van gelowiges aan God en in die kerk van sy Seun nie.

Die lewenswyse van die gelowige is bepalend eerder as die ouderdom.

Daar is plek in die gemeente vir jonger en ouer gelowiges om te dien.

FIGUUR 3 (vervolg...): 1 Timoteus 4:12.

\section{Perikoop:}

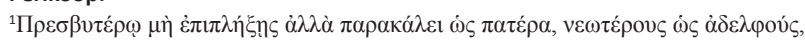

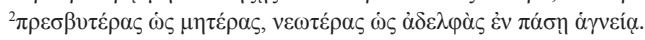

\section{Eie vertaling:}

${ }^{1}$ Moenie ' $n$ ouer man skerp teregwys nie, maar vermaan hom soos ' $n$ vader, jonger mans soos broers, ${ }^{2}$ ouer vroue soos moeders, jonger vroue soos susters, [almal] in alle eerbaarheid.

\section{Plek van die perikoop in die boek}

(Coetzee 1975:104-105

1. Aanhef tot die brief $(1: 1-2)$

1.1 Sender (1:1)

1.2 Geadresseerde (1:2a)

1.3 Seëngroet $(1: 2 b)$

2. Oordrag van die bediening van die ware evangelie aan Timoteus (1:3-20)

2.1 Waarskuwing teen valse lerings (1:3-11)

2.2 Dankbare terugkyk op Paulus se bediening van die Woord (1:12-17)

2.3 Oordrag van die boodskap aan Timoteus (1:18-20)

3. Pastorale opdragte aan Timoteus (2:1-6:10)

3.1 Bid vir alle mense $(2: 1-8)$

3.2 Die plek van vroue in die gemeente (2:9-15)

3.3 Kwalifikasies vir opsigters (3:1-16)

3.4 Toegewyde prediking en afwys van dwaalleer (4:1-16)

3.5 Opdragte oor die bediening van die gemeente $(5: 1-6: 2 a)$

3.5.1 Behandel die gemeente soos familie $(5: 1-2)$

3.5.2 Bediening aan weduwees (5:3-16)

3.5.3 Bediening saam met die ouderlinge (5:17-20)

3.5.4 Onbevooroordeeld en geduldig wees $(5: 21-25)$

3.5.5 Bediening aan slawe $(6: 1-2 a)$

3.6 Valse leraars en ware tevredenheid $(6: 2 b-10)$

4. Persoonlike oproepe tot Timoteus as 'man van God' (6:11-20a)

5. Afsluiting van die brief $(6: 20 b)$

5.1 Seëngroet $(6: 20 b)$

Hierdie perikoop vorm deel van die groter geheel wat opdragte aan Timoteus bevat oor sy bediening in die gemeente (3.5: 5:1-6:2a). Hierdie opdrag fokus op sy gesindheid teenoor lidmate van verskillende ouderdomme, en die kern is dat hy almal in die gemeente - oud en jonk - soos familie moet behandel en bedien.

\section{Genre van die perikoop en van die boek:}

Volgens Bailey en Vander Broek (1992:69) is hierdie perikoop (soos Ef 6:1-4 en Kol 3:20-21) 'n voorbeeld van ' $n$ huistafel. Aune (1987:196-197) verskil egter hiervan. Dat die formulering in die perikoop iets van verhoudings in die huistafels weerspieël, is baie duidelik. Tog verskil dit ook aangesien die oproepe aan Timoteus as die herder van die gemeente gerig is, eerder as aan lidmate. Die perikoop word dus nie as 'n huistafel nie, maar eerder as paraenesis beskou, soortgelyk aan 1 Timoteus 4:12.

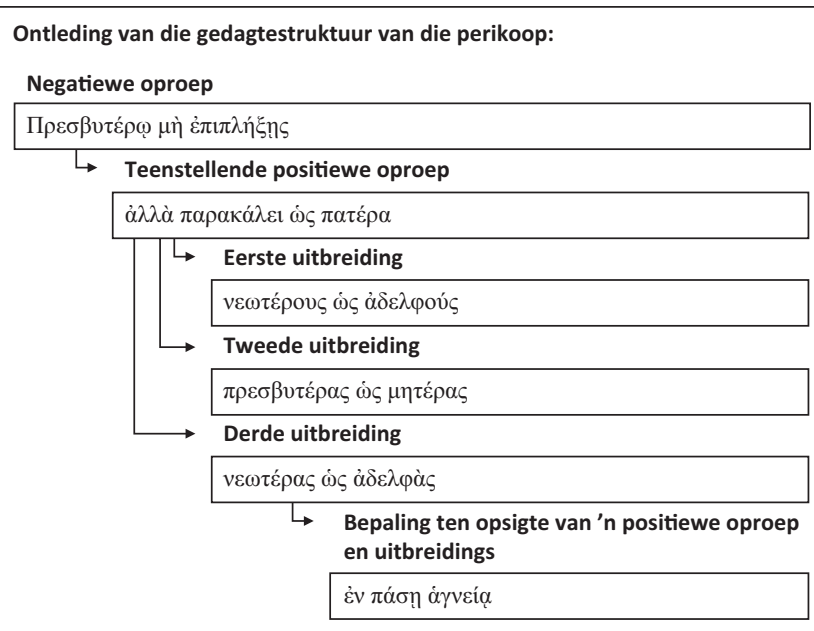




\section{Sosio-historiese konteks van die perikoop:}

Die Grieks-Romeinse huishouding het nie noodwendig net uit die kern van pa, ma en kinders bestaan nie, maar kon ook nie-bloedfamilie en voorouers insluit (Jeffers 1999:239-240). Dit word ook hier in die perikoop afgebeeld, toepas op die gemeente: daar is plek in die huisgesin van God (Ef 2:19) vir alle gelowiges oor bloedlyne en geslagte heen, en hulle verhoudings moet dié in die huishouding weerspieël (Marshall 2004:573-574). Tog wou die skrywers van die Nuwe Testament nie die indruk skep dat hierdie geestelike huisgesin enige werklike huishouding sou ondermyn nie (MacDonald 2010:41-42).

Ten spyte van Timoteus se status as leraar, en die feit dat hy deur die lidmate - ook ouer lidmate - gerespekteer moes word (sien 1 Tim 4:12 hierbo), moes hy ook volgens die norm van die dag respek teenoor ouer lidmate betoon.

\section{Studie van belangrike konsepte in die perikoop:}

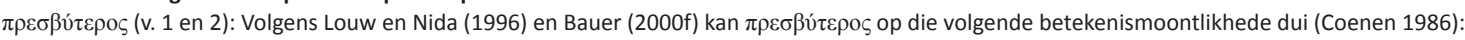

- met betrekking tot die ouer een van twee voorwerpe (67.102 domein 67E Tydsduur sonder verwysing na tydstip of tydeenheid);

- met betrekking tot ' $n$ persoon wat in antieke tye geleef het, dus lank voor die tydstip van die diskoers (67.27 domein 67B ' $n$ Tydstip met verwysing na ' $n$ ander tydstip).

Kontekstueel pas die eerste betekenismoontlikheid die beste.

$\dot{\varepsilon} \pi \imath \lambda \eta \dot{\sigma} \sigma \omega \omega$ (v. 1): Louw en Nida (1996) dui die volgende betekenismoontlikheid aan:

- teregwys as uiting van sterk afkeur (33.420 domein 33T' Teregwys).

Sien ook Bauer (2000h).

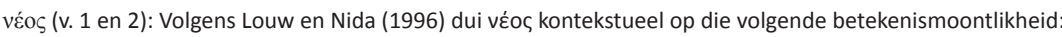

- met betrekking tot ' $n$ mens wat relatief jonk is, dikwels as die jongere van twee mense (67.116 domein 67E Tydsduur sonder verwysing na tydstip of tydeenheid) Sien ook Bauer (2000c).

Die skrywer stel ' $n$ duidelike onderskeid tussen jonger en ouer lidmate in die gemeente (sowel manlik as vroulik by die twee groepe ingesluit). Op grond van antieke bronne sou $\pi \rho \varepsilon \sigma \beta v ́ \tau \varepsilon \rho \circ$ na 'n persoon bo 50 jaar oud kon verwys, maar daar was ook ' $n$ 'rule of thumb' wat persone onder 40 as jonk en persone bo 40 as oud beskou het (Marshall 2004 ). Laasgenoemde is moontlik hier van toepassing.

Openbaringshistoriese konteks van die perikoop:

Die Skrif getuig deurgaans van die feit dat die gemeenskap uit jonk én oud bestaan (vgl. Gen 19:4, 11; Deut 6:7; Jos 6:21; 2 Kon 3:21; Jes 20:4). Binne die gemeenskap van Israel as volk van God is oud en jonk gelyk behandel (vgl. 1 Kron 25:8; 26:13). Hierdie perikoop bevestig dat dit ook die geval in die Vroeë Kerk was - almal is as familie beskou, oud en jonk.

Openbaring oor God in die perikoop:

Alle gelowiges is deel van die huisgesin van God (Ef 2:19) en daarom ook aan mekaar verbind. Jesus se broers en susters is immers hulle wat die wil van die Vader doen (Mark 3:24-25).

Verlossingsfeite in die perikoop:

Christus se verlossingswerk het die effek om gelowiges in 'n nouer verhouding met mekaar te plaas, naamlik dié van 'n geestelike familie.

Oproepe tot jonger en ouer geslagte in die perikoop:

Jonger en ouer geslagte moet mekaar die ruimte en geleentheid gun om werklik familie vir mekaar te wees en mekaar as familie by te staan en te dien, hoewel die wyse waarop die leierskap in die kerk hulle bedien, mag verskil. Leiers moet daarop let dat lidmate in verskillende fases van hulle lewe verskillende behoeftes mag hê, maar dat dit nie die familieband in Christus mag verbreek nie.

Die kommunikasiedoel van die perikoop:

Deur hierdie perikoop motiveer die Heilige Gees kerkleiers om op 'n gepaste wyse na lidmate van verskillende ouderdomme om te sien. Lidmate moet hiervoor ruimte laat sonder om die familieband tussen hulle te laat verslap.

\section{Uitgangspunt(e) afgelei uit die perikoop vir die bediening van jonger en ouer geslagte:}

Daar is ruimte in die gemeente van Christus vir lidmate van alle ouderdomme. Trouens dit word eintlik as vanselfsprekend so aanvaar.

Lidmate moet mekaar se ouderdom in ag neem sonder om die gebondenheid in Christus aan mekaar te laat los.

Kerkleiers moet lidmate se behoeftes in ag neem sonder om die band wat daar in Christus tussen hulle bestaan, te verbreek.

FIGUUR 4 (vervolg...): 1 Timoteus 5:1-2.

\section{Perikoop:}

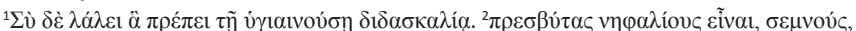

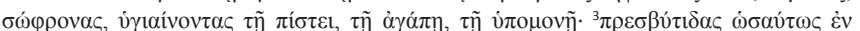

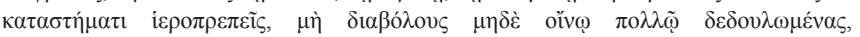

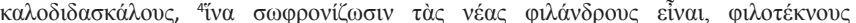

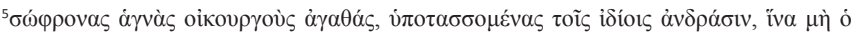

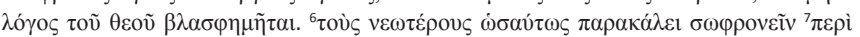

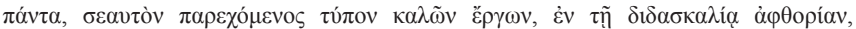

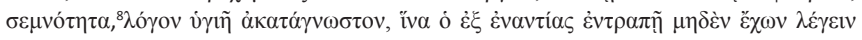

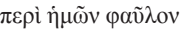

\section{Eie vertaling}

${ }^{1}$ Maar verkondig jy wat pas by die gesonde leer. ${ }^{2}$ Die ouer mans moet selfbeheers wees, waardig, verstandig, gesond in geloof, in liefde, in volharding. ${ }^{3} \mathrm{Net}$ so moet die ouer vroue eerbiedig optree: hulle moenie kwaadpraat of aan wyn verslaaf wees nie, maar wel leer wat goed is, ${ }^{4}$ sodat hulle die jong vroue kan aanmoedig om liefdevo teenoor hulle mans en kinders te wees, ${ }^{5}$ verstandig, kuis, goeie tuisteskeppers, onderdanig aan hulle mans, sodat die woord van God nie belaster word nie. ${ }^{6} \mathrm{Net}$ so moet jy die jonger mans vermaan om verstandig op te tree ${ }^{7}$ in alle opsigte. [En] stel jy self' $n$ voorbeeld deur goeie dade, gesonde leer, waardigheid, ${ }^{8}$ gesonde en onaantasbare prediking, sodat ' $n$ teenstander skaam mag word en niks sleg het om oor ons te sê nie.

Plek van die perikoop in die boek:

(Coetzee (1975:106)

1. Aanhef van die brief (1:1-4)

1.1 Sender $(1: 1-3)$

1.2 Geadresseerde (1:4a)

1.3 Seëngroet $(1: 4 b)$

2. Pastorale opdragte aan Titus (1:5-3:11)

2.1 Verkiesing van en kwalifikasies vir ouderlinge (1:5-9)

2.2 Weerlegging van dwaalleer (1:10-16)

2.3 Pastorale versorging van die oueres, jongeres en slawe (2:1-10)

FIGUUR 5: Titus 2:1-8 


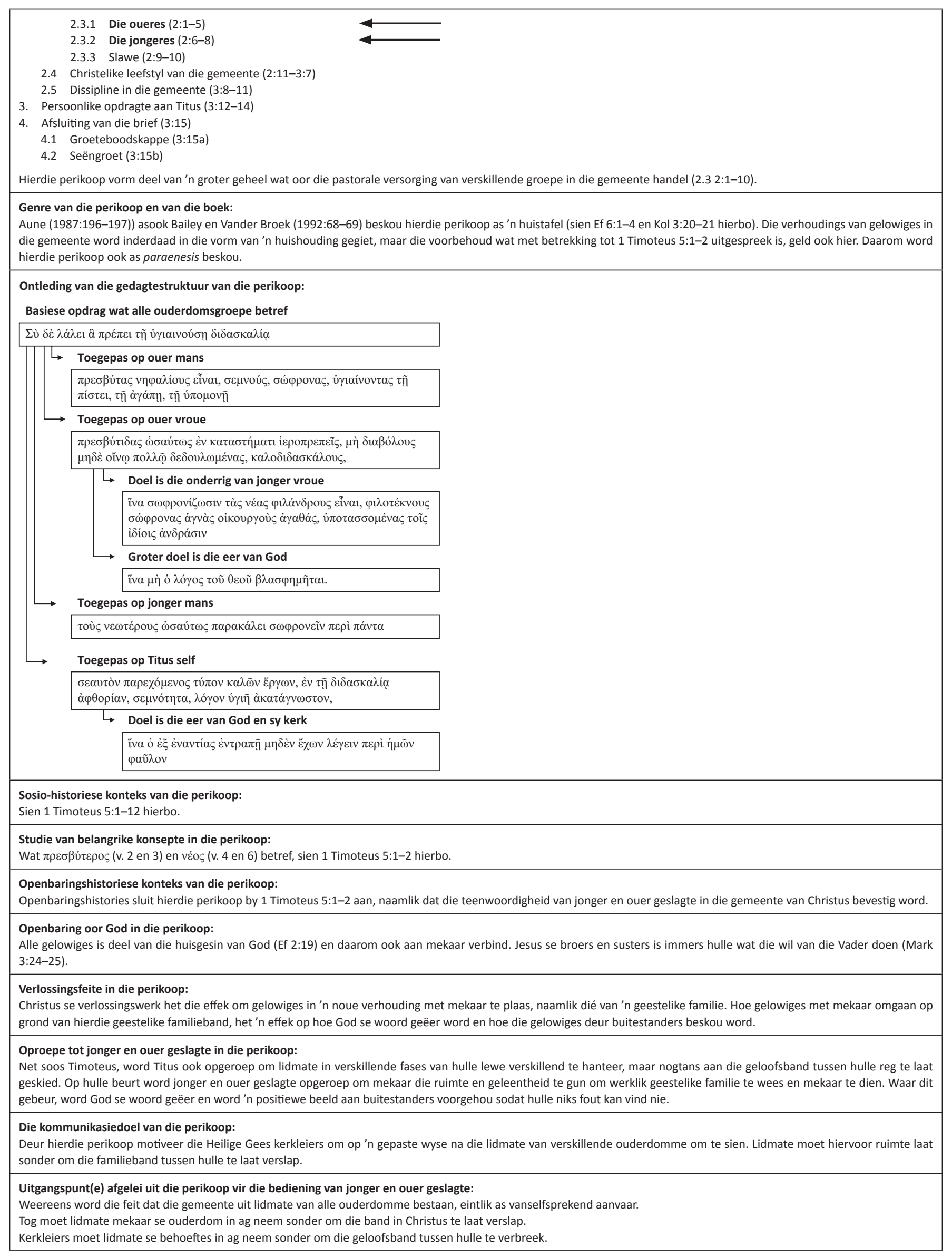

FIGUUR 5 (vervolg...): Titus 2:1-8. 


\section{Perikoop:}

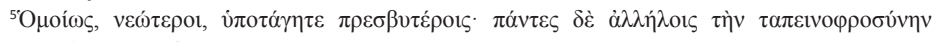
$\dot{\varepsilon} \gamma \kappa о \mu \beta \omega ́ \sigma \alpha \sigma \theta \varepsilon$, о̆ $\tau$

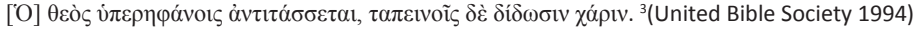

\section{Eie vertaling:}

${ }^{5} \mathrm{Net}$ so moet julle jongeres onderdanig aan die oueres wees. Beklee julle almal met nederigheid teenoor mekaar, want

'God weerstaan hoogmoediges, maar aan nederiges skenk Hy genade'.

\section{Plek van die perikoop in die boek:}

(Vgl. Spr 3:34)

1. Opskrif: Outeur, geadresseerdes, groet (1:1-2)

2. Aanhef van die brief: Basis vir vier gevolgtrekkings in die liggaam van die brief (1:3-12)

2.1 Lof aan God wat ons 'n nuwe lewe gee deur Jesus Christus (1:3-12)

3. Liggaam van die brief: Vier gevolgtrekkings gebaseer op die aanhef van die brief (1:13-5:11)

3.1 Eerste gevolgtrekking: Vestig julle hoop volkome op die genade, en verseker dat julle hele lewenswandel heilig is (1:13-25)

3.2 Tweede gevolgtrekking: 'n Nuutgebore mens se plig teenoor sy persoonlike groei (2:1-3) en teenoor groei met medegelowiges (2:4-10)

3.3 Derde gevolgtrekking: Gedagskode vir vreemdelinge en bywoners (2:11-4:19)

3.3.1 Die basiese oproep (2:11-12)

3.3.2 Verhouding met die politieke owerhede (2:13-17)

3.3.3 Verhouding met slawe-eienaars (2:18-25)

3.3.4 Verhouding met die huweliksmaat (3:1-7)

3.3.5 Verhouding met die medemens in die algemeen (3:8-12)

3.3.6 Houding teenoor en reaksie op onbillike lyding (3:13-4:19)

3.4 Vierde gevolgtrekking: Gedragskode in die kerk (5:1-11)

4. Afsluiting van die brief: Doel van die brief, groete, seëngroet (5:12-14)

Hierdie perikoop vorm deel van 'n groter afdeling wat 'n gedragskode vir gelowiges binne die kerk (dus teenoor mekaar as medegelowiges) bevat (3.4: 5:1-11).

\section{Genre van die perikoop en van die boek:}

Die perikoop sowel as sy groter geheel (5:1-11), bestaan uit paraenesis (Bailey \& Vander Broek 1992:62 e.v.). Hier word die gelowiges kollektief aangespreek en opgeroep om 'n sekere gedragspatroon in die gemeente te volg.

Ontleding van die gedagtestruktuur van die perikoop:

Basiese opdrag aan jonger gelowiges

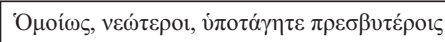

$\longrightarrow$ Kwalifikasie van die basiese opdrag

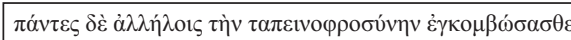

$\longrightarrow$ Ou-Testamentiese gesag

ö $\tau$ ['O] $\theta \varepsilon$ ò

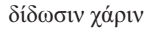

\section{Sosio-historiese konteks van die perikoop:}

Sien 1 Timoteus 5:1-2 hierbo.

Hierdie perikoop bevestig dat die Nuwe Testament 'n baie groter mate van wederkerigheid in die verhoudings in die kerk as die huisgesin van God weerspieël as wat in die GrieksRomeinse wêreld gebeur het (Jeffers 1999:249).

\section{Studie van belangrike konsepte in die perikoop:}

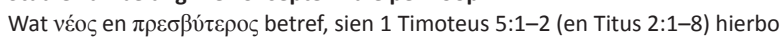

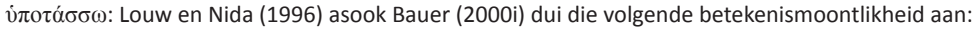

- om iets onder die ferm beheer van iemand te bring (37.31 domein 37A Beheer, onder bedwang hou).

$\dot{\alpha} \lambda \lambda \dot{\eta} \lambda \omega v$ : Volgens Louw en Nida (1996) verwys $\dot{\alpha} \lambda \lambda \dot{\eta} \lambda \omega v$ na die volgende betekenismoontlikheid:

- ' $n$ wederkerige verwysing tussen entiteite (92.26 domein 92E Wederkerige verwysing).

\section{Openbaringshistoriese konteks van die perikoop:}

Weereens word die Skrifopenbaring van die gemeente wat uit jonger en ouer gelowiges, en jonger en ouer geslagte bestaan, bevestig. Anders as in die ander tekste (behalwe by implikasie in Efesiërs 6:1-4) word die wederkerige verhouding tussen jonger en ouer gelowiges hier eksplisiet gestel: hulle is aan mekaar ( $\dot{\alpha} \lambda \lambda \dot{\eta} \lambda \omega v)$ nederigheid verskuldig.

\section{Openbaring oor God in die perikoop:}

God wil dat jongmense onderdanig aan ouer mense moet wees. God slaan nederigheid onder sy kinders hoog aan, en daarom moet gelowiges dit teenoor mekaar betoon, selfs indien die risiko van hoogmoed hoog is, byvoorbeeld waar jongeres op oueres neerkyk omdat hulle te outyds is, of oueres op jongeres neersien omdat hulle te eietyds is.

\section{Verlossingsfeite in die perikoop:}

Die verlossing wat God in Christus vir sy kinders bewerk het, dwing hulle tot nederigheid. Christus wat self God is, het immers slaaf geword ter wille van hulle verlossing (vgl. Fil 2:6-7). As slaaf het Hy nie gekom om gedien te word nie, maar om te dien (Mark 10:45).

Oproep tot jonger en ouer geslagte in die perikoop:

Jonger gelowiges word opgeroep om aan ouer gelowiges onderdanig te wees. Sowel jonger as ouer gelowiges word opgeroep om teenoor mekaar nederig en aan mekaar diensbaar te wees.

Die kommunikasiedoel van die perikoop:

Deur hierdie perikoop motiveer die Heilige Gees jonger gelowiges om hulle ouer medegelowiges te eer, maar die Gees roep ook alle gelowiges op tot nederigheid teenoor mekaar.

Uitgangspunt(e) afgelei uit die perikoop vir die bediening van jonger en ouer geslagte:

Die uitgangspunte afgelei uit die vorige teksgedeeltes word bevestig.

Die verhouding tussen jonger en ouer geslagte word uitdruklik as wederkerig getipeer. Albei groepe is nederigheid aan mekaar verskuldig, en daarom by implikasie diensbaarheid.

FIGUUR 6: 1 Petrus 5:5. 


\section{Perikoop:}

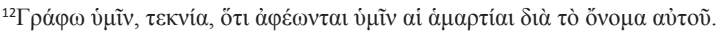

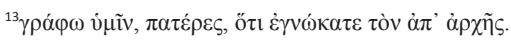

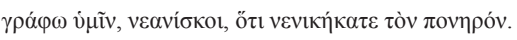

${ }^{14}{ }^{2} \gamma \rho \alpha \psi \alpha$ ن

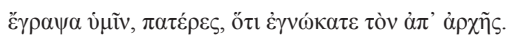

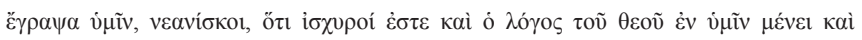

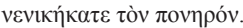

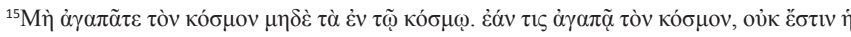

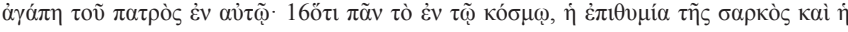

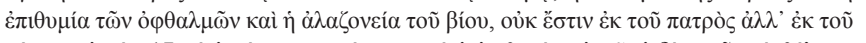

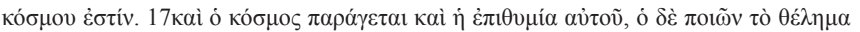

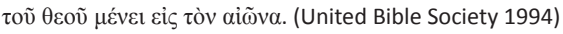

\section{Eie vertaling:}

${ }^{12}$ Ek skryf aan julle, kinders, omdat julle sondes vergewe is op grond van sy Naam.

${ }^{13}$ Ek skryf aan julle, vaders, omdat julle Hom ken wat van die begin af was.

Ek skryf aan julle, jongmense, omdat julle die Bose oorwin het.

${ }^{14} \mathrm{Ek}$ het geskryf aan julle, kinders, omdat julle die Vader ken.

Ek het geskryf aan julle, vaders, omdat julle Hom ken wat van die begin af was.

Ek het geskryf aan julle, jongmense, omdat julle sterk is en die woord van God in julle bly en julle die Bose oorwin het.

${ }^{15}$ Moenie die wêreld of wat in die wêreld is, liefhê nie. As iemand die wêreld liefhet, is die liefde van die Vader nie in hom nie, ${ }^{16}$ want alles is in die wêreld - die begeerte van die liggaam en die begeerte van wat die oë sien en die gespog met goed - is nie van die Vader nie maar is van die wêreld. ${ }^{17} \mathrm{En}$ die wêreld en sy begeertes gaan verby, maar wie die wil van God doen, bly tot in ewigheid.

Plek van die perikoop in die boek:

(Oorgeneem en vertaal uit Thomas 1998)

A - 1:1-4 - Proloog: ewige lewe

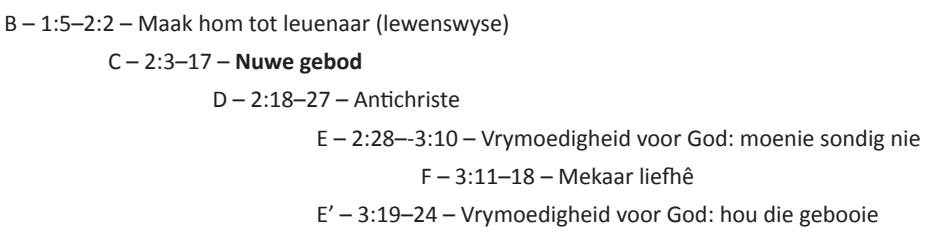

D' - 4:1-6- Antichriste

$C^{\prime}-4: 7-5: 5-$ God se liefde en ons liefde

$B^{\prime}-5: 6-12-$ Maak hom tot leuenaar (getuienis)

$A^{\prime}-5: 13-21-$ Gevolgtrekking: ewige lewe

Hierdie perikoop vorm deel van die afdeling (C) oor die nuwe gebod naamlik om mekaar lief te hê. Die grondslag hiervan is God se liefde vir die gelowiges in Jesus Christus, en die gelowiges se liefde vir God en mekaar wat daaruit voortvloei ( $\left.C^{\prime}\right)$.

Genre van die perikoop en van die boek:

Hoewel 1 Johannes tradisioneel 'n brief genoem word, moet dit eerder as 'n skriftelike preek of homilie beskou word (Coetzee 1990; Kysar 1996:902). Hierdie perikoop kan beskou word as paraenesis binne die groter geheel van die preek aangesien die gemeente tot sekere gedrag opgeroep word.

Ontleding van die gedagtestruktuur van die perikoop:

Teenswoordige skrywes

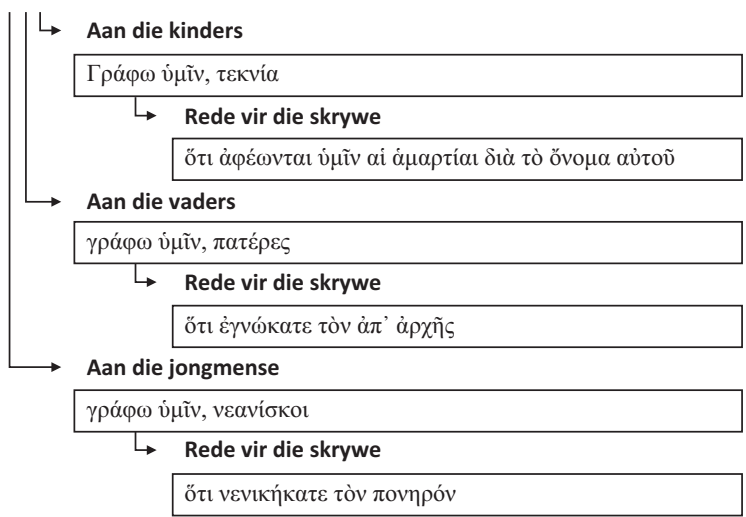

Vorige skrywes

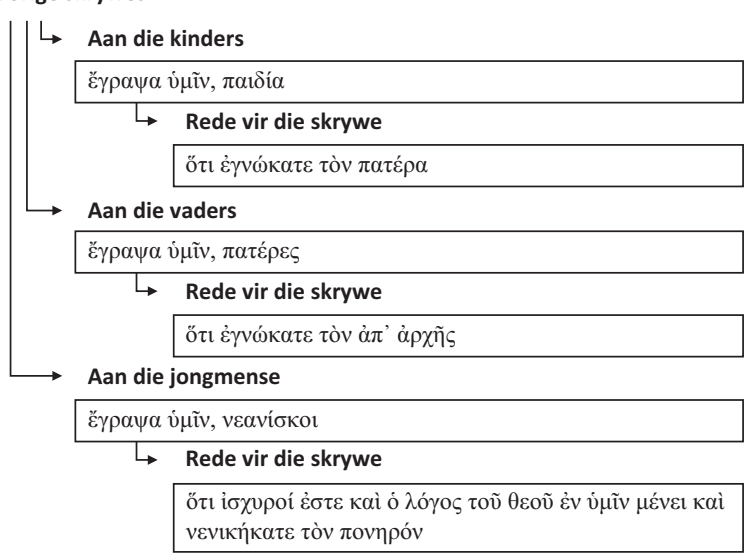

FIGUUR 7: 1 Johannes 2:12-17. 


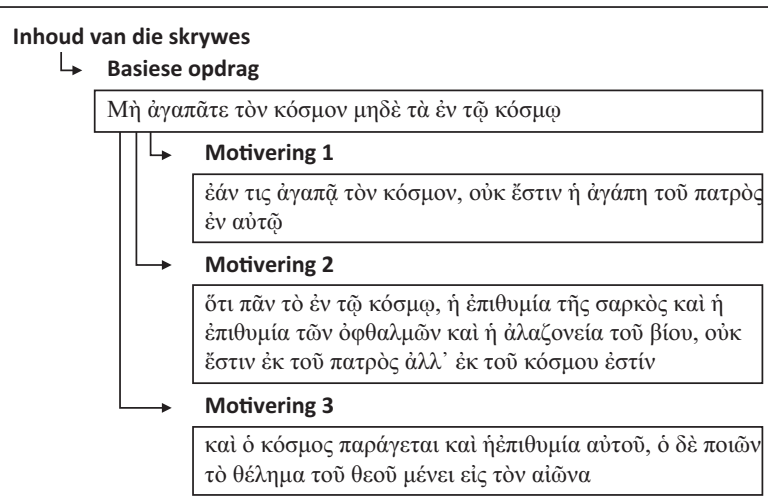

Sosio-historiese konteks van die perikoop:

Aan die einde van die eerste eeu na Christus was die verhoudings in die huishouding nog steeds as model vir gemeente-wees gebruik (Osiek \& Balch 1997).

Studie van belangrike konsepte in die perikoop:

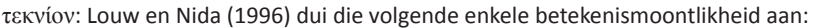

- persoon van enige ouderdom met wie daar 'n besondere verhouding van gehegtheid en assosiasie bestaan (9.46 domein 9E Persone oor wie daar liefdevolle besorgheid bestaan).

Hierdie begrip omvat meer as net bloedbande maar kan na enige hegte verhouding tussen mense verwys, en dus ook die hegte band tussen jonger en ouer gelowiges (Bauer 2000g).

ratń

- iemand se biologiese of aangename manlike ouer (10.14 domein 10B Familieverwantskap oor opvolgende geslagte heen);

- iemand se biologiese of wetlike ouers (altyd in die mv.) (10.18 domein 10B Familieverwantskap oor opvolgende geslagte heen);

- 'n persoon verskeie voorafgaande geslagte verwyder van die verwysde persoon (10.20 domein 10B Familieverwantskap oor opvolgende geslagte heen);

- lid van 'n goed-gedefinieerde sosio-godsdienstige entiteit en verteenwoordigend van 'n ouer ouderdomsgroep as die verwysde persoon (11.26 domein 11B Sosiogodsdienstige groep en klasse persone en hulle lede);

- figuurlike uitbreiding van die letterlike betekenis tot iemand wat die verwysde persoon tot geloof of tot ' $n$ sekere gedragspatroon gelei het (36.8 domein 36A Stuur, lei).

Uit die konteks wil dit blyk dat die betekenis van ratń wyer gaan as biologiese of wetlike manlike ouer, maar dat dit ook grootouers en ander voorouers en ouer gelowiges (ingesluit leiers) binne die gemeente, en selfs geestelike ouers in die figuurlike sin, kan insluit.

veavírкoৎ: Louw en Nida (1996) dui die volgende enkele betekenismoontlikheid aan:

- jong man verby die ouderdom van puberteit maar voor huweliksluiting (9.23 domein 9B Manlike persone).

Die term veavíбкос sou na 'n persoon tussen die ouderdomme van 22 en 28 kon verwys (Marshall 2004:560). In die konteks van die kerk vandag sou sodanige persoon as 'n jongmens beskryf word en hoërskoolkinders, studente en jong werkendes insluit, maar getroudes jongmense uitsluit. Sien ook Bauer (2000h).

Openbaringshistoriese konteks van die perikoop:

Weereens bevestig die perikoop dat die gemeente van Christus as huisgesin van God (Ef 2:19) uit lidmate van verskillende ouderdomsgroepe bestaan. Die gemeente is in sy aard intergenerasioneel (Coulter \& Thompson 2011). Hier word die lyn egter duidelik verby biologiese verwantskappe getrek na geestelike familie-wees.

Openbaring oor God in die perikoop:

God reik uit na alle mense met sy genadige verlossing in Christus - na jonk en oud.

Verlossingsfeite in die perikoop:

God se werksaamheid deur sy Seun is bedoel vir alle gelowiges, ongeag ouderdom. Almal ken God en sy Seun; almal se sondes is vergewe in Jesus se Naam; almal het die Bose oorwin; almal staan sterk en die woord van God bly in hulle.

Oproepe tot jonger en ouer geslagte in die perikoop:

Die oproep om nie die sondige wêreld en die dinge van die wêreld lief te hê nie geld vir kinders, vaders en jongmense - dus vir almal in die gemeente.

Die kommunikasiedoel van die perikoop:

Hoewel die toepassing daarvan mag verskil, byvoorbeeld op grond van verskillende interaksies met tegnologie, bly die basiese evangelieboodskap en die oproep daarvan dieselfde. Dit dui op die eenheid van die gemeente oor ouderdomsgrense heen. Daarin lê ook 'n waarskuwing opgesluit, naamlik dat die kernboodskap nie aangepas mag word om by elke ouderdomsgroep te pas nie.

Uitgangspunt(e) afgelei vir die bediening van jonger en ouer geslagte:

Die verhoudings tussen jonger en ouer lidmate is nie tot bloedverwantskap beperk nie, maar vergestalt ook in geestelike verhoudings tussen jonger en ouer gelowiges.

Die evangelieboodskap wat aan alle gelowiges verkondig word, bly dieselfde aan kinders, volwassenes en aan jongmense.

Die inhoud van die boodskap roep alle gelowiges op om nie die wêreld en die dinge van die wêreld lief te hê nie, maar wel vir God en jou medemens.

Die toepassings van hierdie boodskap mag kontekstueel vir kinders, jongmense en ouer mense verskil.

FIGUUR 7 (vervolg...): 1 Johannes 2:12-17.

- Die verhoudings tussen jonger en ouer lidmate is nie tot bloedverwantskap beperk nie, maar vergestalt ook 'n geestelike verhouding tussen jonger en ouer gelowiges. Geleentheid hiervoor moet prakties geskep word, eerder as bedieningspraktyke wat dit verhinder. Die kerk is immers in sy aard intergenerasioneel.
- Die evangelieboodskap wat aan alle gelowiges verkondig word, bly dieselfde of dit aan kinders, aan volwassenes of aan jongmense gebring word. Die bedienaar(s) van die Woord in'ngemeentemoet daarvoorverantwoordelikheid aanvaar om altyd aan hierdie uitgangspunt reg te laat geskied. Prediking en kategese moet vir alle lidmate 
dieselfde inhoud hê, naamlik om nie die wêreld en die dinge van die wêreld lief te hê nie, maar vir God en jou medemens wel. Natuurlik mag en moet die toepassings van hierdie boodskap kontekstueel vir kinders, jongmense en ouer mense verskil.

\section{Samevatting}

Die Nuwe Testament bied sekere perspektiewe wat lig op die kerklike dilemma van bediening aan jonger en ouer geslagte in een gemeente kan werp. 'n Filologiese studie van relevante tekste toon aan dat die gemeente in sy aard uit jonger en ouer lidmate moet bestaan en dat die bedieningspraktyke aan albei groepe reg moet laat geskied. Hulle is immers almal deel van die huisgesin van God en daarom geestelike broers en susters van mekaar. 'n Gesonde verhouding tussen jonger en ouer geslagte in die kerk word op wedersydse respek, liefde, nederigheid en diensbaarheid gebou. So 'n verhouding word net gebou waar bedieningspraktyke dit prakties toelaat om te ontwikkel en gekoester te word, en waarin ouderdomspesifieke behoeftes met volle integrasie van jonger en ouer geslagte gebalanseer word. In sulke gevalle sal gemeentes nader aan die Nuwe-Testamentiese beeld van 'n kerk beweeg waarin sowel jong as ouer gelowiges 'n plek het om te dien en bedien te word.

\section{Erkenning \\ Mededingende belange}

Die outeur verklaar dat hy geen finansiële of persoonlike verbintenis het met enige party wat hom nadelig kon beïnvloed het in die skryf van hierdie artikel nie.

\section{Literatuurverwysings}

Anthony, M.J., 2011, 'The morphing of the family', in M.J. Anthony \& M.D. Anthony (eds.), A theology of family ministries, pp. 2-20, B \& H Publishing, Nashville, TN.

Aune, D.E., 1987, The New Testament in its literary environment, Westminster Press, Philadelphia, PA.

Bailey, J.L. \& Vander Broek, L.D., 1992, Literary forms in the New Testament: A handbook, Westminster John Knox, Louisville, KY.

Bauer, W., 2000a, ' $\dot{\varepsilon} \rho \varepsilon \dot{i} \zeta \omega^{\prime}$ ', in F.W. Danker (ed.), A Greek-English lexicon of the New Testament and other early Christian literature, p. 391, University of Chicago Press, Chicago, IL.

Bauer, W., 2000b, 'Kúpı ',', in F.W. Danker (ed.), A Greek-English lexicon of the New Testament and other early Christian literature, pp. 576-578, University of Chicago Press, Chicago, IL.

Bauer, W., 2000c, 'véoc', in F.W. Danker (ed.), A Greek-English lexicon of the New Testament and other early Christian literature, p. 669, University of Chicago Press, Chicago, IL.

Bauer, W., 2000d, 'veótns', in F.W. Danker (ed.), A Greek-English lexicon of the New Testament and other early Christian literature, p. 669, University of Chicago Press, Chicago, IL.

Bauer, W., 2000e, 'rapopyi $\zeta \omega$ ', in F.W. Danker (ed.), A Greek-English lexicon of the New Testament and other early Christian literature, p. 780, University of Chicago Press, Chicago, IL.

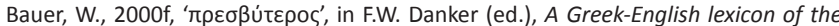
New Testament and other early Christian literature, p. 861, University of Chicago Press, Chicago, IL.

Bauer, W., 2000g, 'זغ́kvov', in F.W. Danker (ed.), A Greek-English lexicon of the New Testament and other early Christian literature, p. 994, University of Chicago Press, Chicago.

Bauer, W., 2000h, 'úraкоúw', in F.W. Danker (ed.), A Greek-English lexicon of the New Testament and other early Christian literature, p. 1028, University of Chicago Press, Chicago, IL.

Bauer, W., 2000i, 'úrotá $\sigma \sigma \omega$ ', in F.W. Danker (ed.), A Greek-English lexicon of the New Testament and other early Christian literature, p. 1042, University of Chicago Press, Chicago, IL

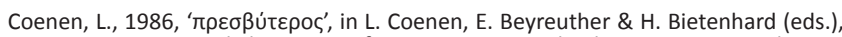
New international dictionary of New Testament theology, p. 199, Zondervan, Grand Rapids, MI.

Coetzee, J.C., 1975, Die blye boodskap: 'n Gids deur die boeke van die Nuwe Testament, vol. 1, Pro Rege, Potchefstroom

Coetzee, J.C., 1990, 'Die Johannesbriewe', in A.B. du Toit (ed.), Handleiding by die Nuwe Testament, pp. 194-209, NG Kerkboekhandel, Pretoria.

Coulter, G.R. \& Thompson, J.W., 2011, 'A theology of grandparenting and generational faith', in M.J. Anthony \& M.D. Anthony (eds.), A theology for family ministries, pp. 135-154, B \& H Publishing, Nashville, TN.

De Klerk, B.J., De Wet, F.W., Lamprecht, A., Nel, M. \& Vergeer, W.C., 2011 Preekgeboorte: Van eksegese tot preek, Potchefstroomse Teologiese Publikasies, Potchefstroom.

Furnish, V.P., 1996a, 'Colossians, epistle to the', in D.N. Freedmen (ed.), The Anchor Bible Dictionary, pp. 1:1090, Doubleday, New York.

Furnish, V.P., 1996b, 'Ephesians, epistle to the', in D.N. Freedmen (ed.), The Anchor Bible Dictionary, pp. 2:536, Doubleday, New York.

Garland, D.R., 1999, Family ministry: A comprehensive guide, InterVarsity, Downers Grove, IL.

Goede, H., 2006, 'Researching ancient texts: A philological and/or linguistic endeavour?', Paper presented at the New Testament Workshop of South Africa, Pretoria, 18th April.

Harrill, J.A., 1998, The manumission of slaves in early Christianity, 2nd edn., Mohr Siebeck, Chicago, IL.

Janse van Rensburg, F., 2000, 'Dékor of konteks?: Die verdiskontering van sosiohistoriese gegewens in interpretasie van 'n Nuwe Testament-teks vir die prediking van pastoraat, geïllustreer aan die hand van die 1 Petrus-brief', Skrif en Kerk 21(3), 564-582.

Jeffers, J.S., 1999, The Greco-Roman world of the New Testament era: Exploring the background of early Christianity, InterVarsity, Downers Grove, IL.

Kysar, R., 1996, 'John, epistles of', in D.N. Freedmen (ed.), The Anchor Bible dictionary, pp. 3:902, Doubleday, New York.

Louw, J.P. \& Nida, E.A., 1996, Greek-English lexicon of the New Testament based on semantic domains, United Bible Societies, New York.

MacDonald, M.Y., 2010, 'Kinship and family in the New Testament world', in D. Neufeld \& R.E. Demaris (eds.), Understanding the social world of the New Testament, pp. 29-43, Routledge, London.

Marshall, I.H., 2004, A critical and exegetical commentary on the pastoral epistles, Clark, London.

Mundle, W., 1986, 'u்rakoúw', in L. Coenen, E. Beyreuther \& H. Bietenhard (eds.), New international dictionary of New Testament theology, p. 179, Zondervan, Grand Rapids, MI.

Osiek, C. \& Balch, D.L., 1997, Families in die New Testament world: Households and house churches, Westminster John Knox Press, Louisville, KY.

Renfro, P., Shields, B. \& Strother, J., 2009, Perspectives on family ministry: 3 Views, B \& H Publishing, Nashville, TN.

Thomas, J.C., 1998, 'The literary structure of 1 John', Novum Testamentum 40(4), 369-381. http://dx.doi.org/10.1163/156853698323282117

United Bible Society, 1994, Greek Bible with dictionary, 4th rev. edn., Deutsche Bibelgesellschaft, Stuttgart.

Van Staden, J.M., 2014, 'Gesinsbediening in 'n postmoderne kerk: Modelle en metodes', HTS Teologiese Studies/Theological Studies 70(1), 8. http://dx.doi. org/10.4102/hts.v70i1.2783

Van Staden, J.M. \& Dreyer, Y., 2013, 'Gesinsbediening in 'n postmoderne kerk vanuit Bybels-teologiese perspektiewe', HTS Teologiese Studies/Theological Studies 69(1), 7. http://dx.doi.org/10.4102/hts.v69i1.2049 